WOODHFAD PLBL.ISHING SFRIFS IN BIOMATERIALS

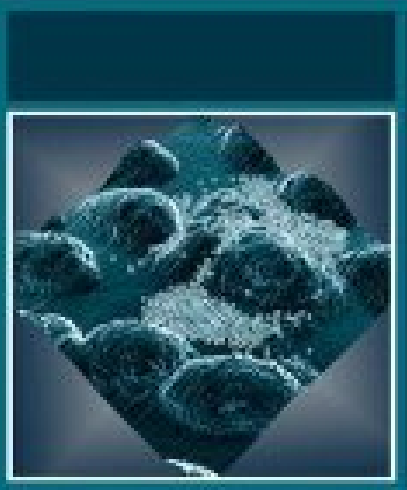

New functional

biomaterials for

medicine and

healthcare

Elena P. Ivanova, Kateryna Bazaka and Russell J. Crawford 
New functional biomaterials for medicine and healthcare 


\section{Related titles:}

Biomaterials for cancer therapeutics

(ISBN 978-0-85709-664-7)

Biomedical imaging

(ISBN 978-0-85709-127-7)

Porous silicon for biomedical applications

(ISBN 978-0-85709-711-8)

Details of these books and a complete list of titles from Woodhead Publishing can be obtained by:

- visiting our web site at www.woodheadpublishing.com

- contacting Customer Services (e-mail: sales@woodheadpublishing.com; fax: +44 (0) 1223 832819; tel.: +44 (0) 1223499140 ext. 130; address: Woodhead Publishing Limited, 80, High Street, Sawston, Cambridge CB22 3HJ, UK)

- in North America, contacting our US office (e-mail: usmarketing@ woodheadpublishing.com; tel.: (215) 928 9112; address: Woodhead Publishing, 1518 Walnut Street, Suite 1100, Philadelphia, PA 19102-3406, USA)

If you would like e-versions of our content, please visit our online platform: www. woodheadpublishingonline.com. Please recommend it to your librarian so that everyone in your institution can benefit from the wealth of content on the site.

We are always happy to receive suggestions for new books from potential editors. To enquire about contributing to our Biomaterials series, please send your name, contact address and details of the topic/s you are interested in to laura.overend@ woodheadpublishing.com. We look forward to hearing from you.

\section{The team responsible for publishing this book:}

Commissioning Editor: Francis Dodds

Project Editor: Elizabeth Moss

Editorial and Production Manager: Mary Campbell

Production Editor: Mandy Kingsmill

Project Manager: Annette Wiseman, RCL

Copyeditor: Jo Egré

Freelance Proofreader: Clare Dobson

Cover Designer: Terry Callanan 


\section{New functional biomaterials for medicine and healthcare}

Elena P. Ivanova, Kateryna Bazaka and Russell J. Crawford

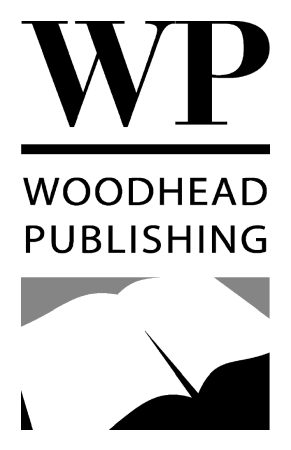

Oxford Cambridge Philadelphia New Delhi 
Published by Woodhead Publishing Limited, 80 High Street, Sawston, Cambridge CB22 3HJ, UK

www.woodheadpublishing.com

www.woodheadpublishingonline.com

Woodhead Publishing, 1518 Walnut Street, Suite 1100, Philadelphia, PA 19102-3406, USA

Woodhead Publishing India Private Limited, 303, Vardaan House, 7/28 Ansari Road, Daryaganj, New Delhi - 110002, India

www.woodheadpublishingindia.com

First published 2014, Woodhead Publishing Limited

(C) Woodhead Publishing Limited, 2014. The publisher has made every effort to ensure that permission for copyright material has been obtained by authors wishing to use such material. The authors and the publisher will be glad to hear from any copyright holder it has not been possible to contact.

The authors have asserted their moral rights.

This book contains information obtained from authentic and highly regarded sources. Reprinted material is quoted with permission, and sources are indicated. Reasonable efforts have been made to publish reliable data and information, but the authors and the publishers cannot assume responsibility for the validity of all materials. Neither the authors nor the publishers, nor anyone else associated with this publication, shall be liable for any loss, damage or liability directly or indirectly caused or alleged to be caused by this book.

Neither this book nor any part may be reproduced or transmitted in any form or by any means, electronic or mechanical, including photocopying, microfilming and recording, or by any information storage or retrieval system, without permission in writing from Woodhead Publishing Limited.

The consent of Woodhead Publishing Limited does not extend to copying for general distribution, for promotion, for creating new works, or for resale. Specific permission must be obtained in writing from Woodhead Publishing Limited for such copying.

Trademark notice: Product or corporate names may be trademarks or registered trademarks, and are used only for identification and explanation, without intent to infringe.

British Library Cataloguing in Publication Data

A catalogue record for this book is available from the British Library.

Library of Congress Control Number: 2013948572

ISBN 978-1-78242-265-5 (print)

ISBN 978-1-78242-266-2 (online)

ISSN 2049-9485 Woodhead Publishing Series in Biomaterials (print)

ISSN 2049-9493 Woodhead Publishing Series in Biomaterials (online)

The publisher's policy is to use permanent paper from mills that operate a sustainable forestry policy, and which has been manufactured from pulp which is processed using acid-free and elemental chlorine-free practices. Furthermore, the publisher ensures that the text paper and cover board used have met acceptable environmental accreditation standards.

Typeset by RefineCatch Limited, Bungay, Suffolk

Printed by Lightning Source 
Author contact details

$(*=$ main contact $)$

Elena P. Ivanova*

Faculty of Life and Social Sciences

Swinburne University of Technology

Mail H31

PO Box 218

Hawthorn, Victoria 3122

Australia

E-mail: eivanova@swin.edu.au
Kateryna Bazaka

James Cook University

Australia

E-mail: katia.bazaka@my.jcu.edu.au

Russell J. Crawford

Swinburne University of Technology Australia

E-mail: rcrawford@swin.edu.au 


\section{Woodhead Publishing Series in Biomaterials}

1 Sterilisation of tissues using ionising radiations

Edited by J. F. Kennedy, G. O. Phillips and P. A. Williams

2 Surfaces and interfaces for biomaterials

Edited by P. Vadgama

3 Molecular interfacial phenomena of polymers and biopolymers

Edited by $C$. Chen

4 Biomaterials, artificial organs and tissue engineering

Edited by L. Hench and J. Jones

5 Medical modelling

R. Bibb

6 Artificial cells, cell engineering and therapy

Edited by S. Prakash

7 Biomedical polymers

Edited by M. Jenkins

8 Tissue engineering using ceramics and polymers

Edited by A. R. Boccaccini and J. Gough

9 Bioceramics and their clinical applications

Edited by T. Kokubo

10 Dental biomaterials

Edited by R. V. Curtis and T. F. Watson

11 Joint replacement technology

Edited by P. A. Revell

12 Natural-based polymers for biomedical applications

Edited by R. L. Reiss et al

13 Degradation rate of bioresorbable materials

Edited by F. J. Buchanan

14 Orthopaedic bone cements

Edited by S. Deb

15 Shape memory alloys for biomedical applications

Edited by T. Yoneyama and S.Miyazaki

16 Cellular response to biomaterials

Edited by L. Di Silvio

17 Biomaterials for treating skin loss

Edited by D. P. Orgill and C. Blanco 
18 Biomaterials and tissue engineering in urology

Edited by J. Denstedt and A. Atala

19 Materials science for dentistry

B. W. Darvell

20 Bone repair biomaterials

Edited by J. A. Planell, S. M. Best, D. Lacroix and A. Merolli

21 Biomedical composites

Edited by L. Ambrosio

22 Drug-device combination products

Edited by A. Lewis

23 Biomaterials and regenerative medicine in ophthalmology

Edited by T. V. Chirila

24 Regenerative medicine and biomaterials for the repair of connective tissues Edited by C. Archer and J. Ralphs

25 Metals for biomedical devices Edited by M. Ninomi

26 Biointegration of medical implant materials: science and design Edited by C. P. Sharma

27 Biomaterials and devices for the circulatory system Edited by T. Gourlay and R. Black

28 Surface modification of biomaterials: methods analysis and applications Edited by R. Williams

29 Biomaterials for artificial organs Edited by M. Lysaght and T. Webster

30 Injectable biomaterials: Science and applications Edited by B. Vernon

31 Biomedical hydrogels: Biochemistry, manufacture and medical applications Edited by S. Rimmer

32 Preprosthetic and maxillofacial surgery: Biomaterials, bone grafting and tissue engineering Edited by J. Ferri and E. Hunziker

33 Bioactive materials in medicine: Design and applications Edited by X. Zhao, J. M. Courtney and H. Qian

34 Advanced wound repair therapies Edited by D. Farrar

35 Electrospinning for tissue regeneration Edited by L. Bosworth and S. Downes

36 Bioactive glasses: Materials, properties and applications Edited by H. O. Ylänen

37 Coatings for biomedical applications Edited by M. Driver

38 Progenitor and stem cell technologies and therapies Edited by A. Atala

39 Biomaterials for spinal surgery Edited by L. Ambrosio and E. Tanner

40 Minimized cardiopulmonary bypass techniques and technologies Edited by T. Gourlay and S. Gunaydin

41 Wear of orthopaedic implants and artificial joints Edited by $S$. Affatato 
42 Biomaterials in plastic surgery: Breast implants

Edited by W. Peters, H. Brandon, K. L. Jerina, C. Wolf and V. L. Young

43 MEMS for biomedical applications

Edited by S. Bhansali and A. Vasudev

44 Durability and reliability of medical polymers

Edited by M. Jenkins and A. Stamboulis

45 Biosensors for medical applications

Edited by S. Higson

46 Sterilisation of biomaterials and medical devices

Edited by S. Lerouge and A. Simmons

47 The hip resurfacing handbook: A practical guide to the use and management of modern hip resurfacings

Edited by K. De Smet, P. Campbell and C. Van Der Straeten

48 Developments in tissue engineered and regenerative medicine products

J. Basu and J. W. Ludlow

49 Nanomedicine: technologies and applications

Edited by T. J. Webster

50 Biocompatibility and performance of medical devices

Edited by J-P. Boutrand

51 Medical robotics: minimally invasive surgery

Edited by P. Gomes

52 Implantable sensor systems for medical applications

Edited by A.Inmann and D.Hodgins

53 Non-metallic biomaterials for tooth repair and replacement

Edited by P. Vallittu

54 Joining and assembly of medical materials and devices

Edited by Y. (Norman) Zhou and M. D. Breyen

55 Diamond-based materials for biomedical applications

Edited by R.Narayan

56 Nanomaterials in tissue engineering: Fabrication and applications

Edited by A. K. Gaharwar, S. Sant, M. J. Hancock and S. A. Hacking

57 Biomimetic biomaterials: Structure and applications

Edited by A. J. Ruys

58 Standardisation in cell and tissue engineering: Methods and protocols

Edited by V. Salih

59 Inhaler devices: Fundamentals, design and drug delivery

Edited by P. Prokopovich

60 Bio-tribocorrosion in biomaterials and medical implants

Edited by Y. Yan

61 Microfluidic devices for biomedical applications

Edited by X-J. James Li and Y. Zhou

62 Decontamination in hospitals and healthcare

Edited by J. T. Walker

63 Biomedical imaging: Applications and advances

Edited by P. Morris

64 Characterization of biomaterials

Edited by M. Jaffe, W. Hammond, P. Tolias and T. Arinzeh

65 Biomaterials and medical tribology

Edited by J. Paolo Davim 
66 Biomaterials for cancer therapeutics: Diagnosis, prevention and therapy Edited by K. Park

67 New functional biomaterials for medicine and healthcare E. P. Ivanova, K. Bazaka and R. J. Crawford

68 Porous silicon for biomedical applications Edited by H. A. Santos

69 A practical approach to spinal trauma Edited by H. N. Bajaj and S. Katoch

70 Rapid prototyping of biomaterials: Principles and applications Edited by R.Narayan

71 Cardiac regeneration and repair Volume 1: Pathology and therapies Edited by R.-K. Li and R. D. Weisel

72 Cardiac regeneration and repair Volume 2: Biomaterials and tissue engineering Edited by R.-K. Li and R. D. Weisel

73 Semiconducting silicon nanowires for biomedical applications Edited by J.L. Coffer

74 Silk for biomaterials and tissue engineering applications Edited by S.Kundu

75 Novel biomaterials for bone regeneration: Novel techniques and applications Edited by P. Dubruel and S. Van Vlierberghe

76 Biomedical foams for tissue engineering applications Edited by P. Netti

77 Precious metals for biomedical applications Edited by N. Baltzer and T. Copponnex

78 Bone substitute biomaterials Edited by K. Mallick

79 Regulatory affairs for biomaterials and medical devices Edited by S. Amato and R. Ezzell

80 Joint replacement technology Second edition Edited by P. A. Revell

81 Computational modelling of biomechanics and biotribology in the musculoskeletal system: Biomaterials and tissues Edited by Z. Jin

82 Biophotonics for medical applications Edited by I. Meglinski

83 Modelling degradation of bioresorbable polymeric medical devices Edited by J. Pan

84 Perspectives in total hip arthroplasty: Advances in biomaterials and their tribological interactions S. Affatato

85 Tissue engineering using ceramics and polymers Second edition Edited by A. R. Boccaccini and P. X. Ma 


\section{Preface}

As far back as antiquity, materials foreign to the human body have been employed to mitigate and repair damage caused by disease, defect or trauma. Indeed, some 2000 years ago, the Chinese, Aztecs and Romans were already using soft and malleable gold to fill tooth cavities, and high strength, relatively lightweight wood for limb and tooth prosthetics. East African indigenous tribal people and the Indians of Central America used siafu and bullet ants, respectively, as a handy source of emergency sutures. They would apply an ant close to the wound, letting the ant bite into the flesh, and then twist the ant's head off. The ant's very strong pincer-like mandibles would hold the wound closed tight and the ant's saliva would cause local swelling in the skin, hermetically sealing the wound.

To a large extent, early biomaterial enthusiasts were confined to using natural materials available in their immediate environment. Much has changed since those early days - gashes are no longer sutured using ant pincers and wooden prosthesis gave way to sophisticated creations made of plastics, carbon fibre, metals and ceramics. The twentieth century has seen a significant shift from naturally occurring biomaterials to synthetic polymers, alloys and composites. These novel materials had numerous advantages, including enhanced mechanical, chemical and biological performance, improved and augmented functionality, and high reproducibility. Importantly, their properties could be tailored to a specific application by controlling input materials and synthesis parameters.

Rapid advancements in other areas of technology provided many a material that later found its way into biomedical applications. Similarly, numerous material synthesis, fabrication and modification techniques have been adopted for biomaterial production from other industries. These developments resulted in an unprecedented increase in the number, variety, complexity, efficacy and range of applications of biomaterials. Countless patients had their lives saved and their lifestyle and productivity upheld or enhanced thanks to biomaterials-based implantable and extracorporeal devices.

However, not until the molecular biology revolution of the 1970s and advances in genomics and proteomics in the 1990s and 2000s, was the potential of biomaterials to restore lost or damaged function fully appreciated. These 
developments also fundamentally changed our understanding of what properties of biomaterials should be in order to achieve adequate integration within living tissues, altering the manner in which modern biomaterials are developed and used. It is during this period that biomaterials science has transitioned from a practitioner-driven discipline to a multidisciplinary field of science that encompasses many traditional and emerging scientific and engineering disciplines and clinical practices. The discovery of a complex relationship between chemical and physical properties of biomaterials and the biological response they illicit in vitro and in vivo further cemented the interdisciplinary nature of biomaterials science.

Just as in the nature of the biomaterials discipline itself, the expertise of the authors of this book spans many disciplines, from fundamental materials science, chemistry and physics, to nanoscale engineering, biochemistry and microbiology. From polymers to metals to enhanced natural materials, New functional biomaterials for healthcare and medicine reviews a plethora of currently available knowledge within the area, offering a refined blend of basic science, engineering and medical experience. Topics covered in this book range from discussions on critical issues pertaining to human use of biomaterials and contemporary trends in biomaterials fabrication, to surveys of current and prospective applications of major classes of biomaterials, and their fundamental properties, performance and shortcomings.

Being material- rather than application-orientated, each topic offers a comprehensive and succinct digest of essential concepts pertinent to a particular class of biomaterials, which makes this book an equally suitable reference for materials scientists concerned with specific properties and those professionals seeking to enhance their understanding of materials' biocompatibility, integration and cytotoxicity. The language and content of this book will appeal to students, aspiring and practising scientists, and engineers who are interested in becoming acquainted with major issues associated with biomaterials sciences and current models to combat those issues. Complementary skills and the diverse scientific background of the authors ensure that complex ideas are delivered using simple scientific language, avoiding overcomplicated equations and discipline-specific jargon, so making this book a suitable read for a wide audience. A laconic reference to articles published in leading journals is included to support the concept and enhance the reader's understanding of the issues, without making the book overly detailed or too technical for the readership.

This book would not have been possible without the time and energy invested by scientists and engineers into the development of the biomaterials covered. Their contributions to biomaterials science have formed the foundation for this work, and we are grateful for their efforts in transforming the lives of patients worldwide. Many thanks to our collaborators, colleagues, industry and clinical partners and postgraduate students, as their expertise and stimulating discussions have contributed significantly to the quality of this work. We are particularly 
grateful to many co-authors who over the years have made major contributions to original articles featured in this book. We would also like to acknowledge the staff at Woodhead Publishing Ltd, for their excellent organisational and editorial skills, helpful attitude and support, which ensured successful completion of this work. Last but not the least, we thank our families for their support, encouragement and understanding, for many a family weekend has been spent writing this book. We would also like to thank the Australian Research Council, James Cook University, Swinburne University of Technology, and Australian Institute of Nuclear Science and Engineering, who supported our research endeavours and this work.

Elena Ivanova, Kateryna Bazaka and Russell Crawford 